\title{
Overeducation and Mismatches at the Labour Market - Albania Case
}

\author{
Migen Elmazaj, PhD Cand. \\ University of Tirana, Faculty of Natural Sciences \\ megielmazi@gmail.com
}

Alma Kondi

University of Tirana, Faculty of Economy

alma.kondi@yahoo.com

\begin{abstract}
There is a constant increase in the graduates supply in the labour market in Albania. It seems that the expansion is going on a basis that risks distorting the distribution of students not in line with labor market needs. These expansions have been predicated on the assumption that more education is good for individuals and for society as a whole, not only in terms of economic outcomes like wages or employment, but also for a wide range of social outcomes like improved health and higher well-being. However, along with expansion of the system has come a range of new questions that have emerged as consequence of being many more tertiary graduates. For example, has the increase in tertiary graduates resulted in an oversupply of workers with tertiary qualifications, and thus a decline in the 'value of a degree?' If overeducation is a temporary disequilibrium or a permanent feature of economy; if the subject of degree affects the likelihood of being overeducated etc. are raised. This paper represents a research, aiming a total covering of the labour market measuring the overeducation rate for the graduates in Albania and drawing some take aways. The main contribution of the paper consists in providing estimations of graduate overeducation rate in national level. Some guidelines for possible recommendations for policies makers, relevant government agencies, higher education institutions, parents and other stakeholders involved in higher education sector in Albania, are also provided.
\end{abstract}

Keywords: Overeducation, Labour market, Higher Education, Graduates

\subsection{Introduction}

In recent decades, Albania has gone through a process of expanding education, where an important part consisted in Higher Education (HE). The number of students in Albania has been increased significantly. Reforms launched in the field of education allowed universities to expand and at the same time newly created institutions received the university status. From 1994 to 2002 the number was increased about $67 \%$, and in 2002 was opened the first private university in Albania. In a period of 13 years the number increased again, reaching 173,819 in 2013/2014 academic year. There has been doubt that the labour market could absorb such a rapidly expanding supply of new graduates. It should be noted that this change in quantity was unusual for the capacities of Albania and for the opportunities it offers. This massification process, perhaps important as educational policy, was not done in phases by studying them. This factor led to a certain extent in the decrease, sometimes dramatically of the quality, instead of its expected improvement. By 2014, the Albanian system of higher education presented the following configurations: A total of 59 institutions of higher education, 15 public and 44 private ones.

But the increased education' level of the work force was not followed at the same time by a work structure growth, in order to match the number of graduates. Consequently the phenomenon of overeducation appeared. Numerous questions have been raised about the impact that this expansion will bring in the labor market demand and supply. On the supply side, questions arise about the quality of new graduates. It is believed that the quality of graduates has declined in the last years as result of several factors such as overcrowding of universities, introduction of new programs with lower academic content to suit students with lower level skills, etc. 
The process of expansion of higher education in Albania is considered by some as a good one, and even necessary, in order to meet the growing demand for skills that is naturally associated with the need of a society of knowledge. Furthermore one could argue that it is always good to have well-educated people, because education exerts positive effects on an active citizenship. It cannot exist something as redundant education.

For another group, the expansion of education is not necessarily always positive. Hartog ${ }^{1}(2000)$ suggests that "the expansion of participation in HE has exceeded the required levels of education". Based on this view, the risk of devaluation of degrees, and consequently social degradation of higher education graduates, becomes real. Overeducation is associated with low productivity and low job satisfaction. Moreover, if overeducation exists, this may result in a loss of social and individual resources. This has raised concerns about the value of higher education and challenges the widely held belief that a university education is a good investment and a guarantee of economic success.

A reform in higher education in Albania is under way since October 2013. The main pillar and objective of this reform is quality improvement and enhancement in higher education. Long term actions are on the way such as the Platform for Reforming Higher Education and a new Higher Education Law.

On this framework during January-July 2014, the Ministry of Education, the National Inspectorate for Higher Education and PAAHE, in a joint process undertook a thorough evaluation of 59 public and private HEls, for the verification of the compliance with Albanian legislation, national standards and guidelines for HE. Quality Criteria were part of the evaluation and verification process and procedure. The outcome of this process was license revoking and final closure for 21 out of 44 Private Higher Education Institutions, license suspension for other 4 private HEls and Recommendations for 13 private and 15 public HEls².

As for 2015 we have active on the market 15 Public HEl's and 23 Private HEl's as below

Graphic 1

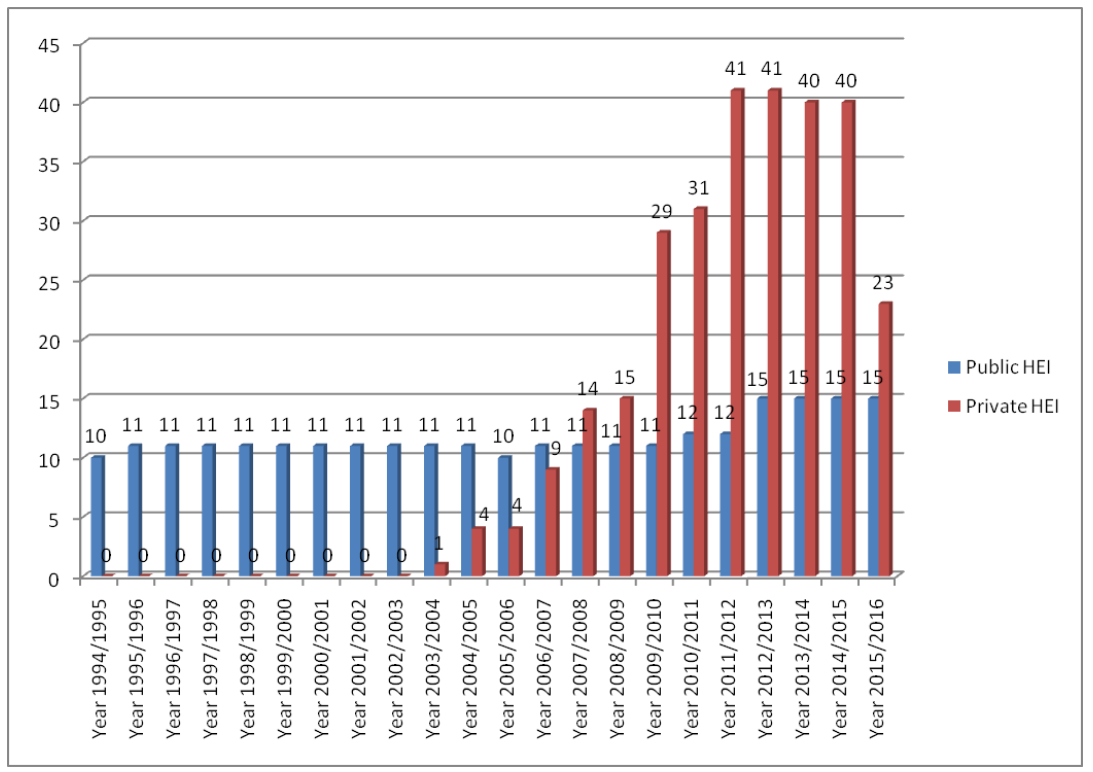

Graphic 2

1 Hartog, J. (2000). "Over-education and earnings: where are we and where should we go?" Economics of Education Review 19: 131

2 Public Agency for Acredition of Higher Education in Albania, www.aal.edu.al 


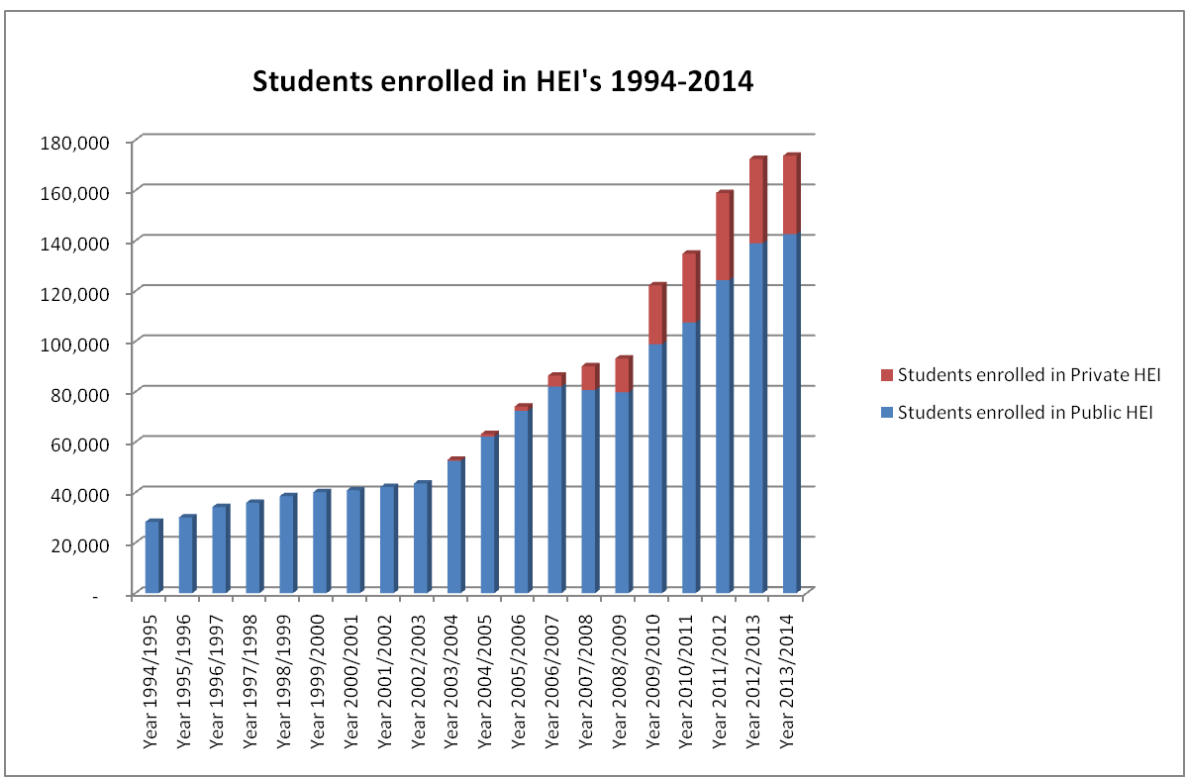

Source of data: INSTAT

Prepared by: M.Elmazaj

As we see from the graphics, the largest number of students belongs to public HEl's. As for academic year 2013/2014 we have 142'707 students enrolled in public HEl's compared with 31'112 students enrolled in private HEl's. So the closure of $21 \mathrm{HEl}$ 's didn't bring any considerable difference in the total number of students enrolled in HEls. The total number of students registered in these HEls was $9^{\prime} 721$, which represents only $6 \%$ of the total number of students. Even more these students were redistributed to the other active HEl's.

This paper provides a brief account on this phenomenon which has become a major concern as it proves to be pervasive, widespread and persistent resulting on real costs on individuals, businesses and society as a whole. To successfully overcome this challenge, the major concern is to be able to measure it appropriately.

The main emphasis is put on explaining measurement methods and to provide datas of a study on existence of the overeducation phenomenon in Albania. Questions like "is over education a temporary disequilibrium or a permanent feature of economy"; "is the over education likely to happen in specific fields of education, or is it an indistinct phenomenon", etc. are raised. The objectives of the survey required the use of a standardized questionnaire as the core research instrument in order to collect the data. On this regards, a study was conducted. The questionnaire addressed the socio-biographic profile of the graduates, their study experiences, their employment, work and careers since graduation and the links they perceive between education and work. Special emphasis in the data analysis was put on procedures of multivariate analysis in order to identify the most influential elements on the relationships between higher education and employment. The findings indicate that the phenomenon exists in Tirana and that the temporary over education is associated with an early stage in the occupational career.

\subsection{Overeducation Measurement Methods}

The literature distinguishes three methods to measure this phenomenon.

First method pertains to job analysts determining the level of education required for a job (eg, Rumberger, 1987 ${ }^{1}$ ). This is an objective method which includes a detailed analysis of the professions and is based on the assessment of the

1 Rumberger, R.W (1987), 'The Impact of Surplus Schooling on Productivity and Earnings', The Journal of Human Resource, vol. 22, no. 1. 
educational level required to perform a job. The analysts consider as the required level of education the one that enables satisfactory performance of these specific tasks and define individuals as over-educated if their education exceeds the estimated / required level.

In US research, we can refer to the Dictionary of Occupational Titles (DOT). In UK, we refer to the Standard Occupational Classifications (SOC). In Albania in June 2009 the "National List of Professions" document is approved. Halaby (1994) ${ }^{1}$ raises two important objections to this method. The first concerns the fact that a fixed job level is attached to a certain job. Any variation of job levels within a given occupation is not taken into account. However, variation within a given occupation with regard to educational requirements may be considerable. This particularly affects the reliability of the measurement instrument. The second objection is that the allocation of the levels is determined by job analysts. This is often done on the basis of descriptions of the tasks and the nature and required level of knowledge and skills. However, these are subject to change, which might result in a systematic overestimation or underestimation of the level of certain occupations. Furthermore, there is not always a consensus - even among experts - about the level of education required for a given occupation. This affects particularly the validity of the measurement instrument

Second method, is a subjective method and is based on the employee Self Assesment (SA) regarding the minimal educational level required in his job position, or the utilisation rate of knowledge acquired at work (ex., Duncan dhe Hoffman, 19812). This method is named as indirect self assesment (ISA) unlike other methods which measure overeducation based more in direct self assesment (DSA)

So employees are asked directly what they regard as the required level of education for the position they hold by asking: "How much formal education is required to get a job like yours?" This method does not go uncriticised, either. The subjective character of the instrument is a point of criticism, as is the fact that respondents may not always have a good insight in the level of education required for a job (Cohn and Khan, 19953; Halaby, 1994). Hartog and Jonker (1998) ${ }^{4}$ have pointed out that individuals may be inclined to overestimate the educational requirements or to simply equate these to their own level of education. In that case, the level of overeducation will be underestimated, which affects the validity.

Third method Realized Matches (RM) is a statistical approach. This method takes the average of the actual levels of education of those employed in a certain occupation as its basis (Verdugo \&Verdugo, 19895) or MODAL (Kiker, 1997) ${ }^{6}$. A limit of one standard deviation above or beneath this average is taken as a criterion for overeducation or undereducation (Verdugo and Verdugo, 1989). Again, this method ignores the variation in educational requirements within an occupation, while the limit of one standard deviation would also seem rather arbitrary (Halaby, 1994). Furthermore, this method is very sensitive to changes in labour market conditions. In case of excess supply, employers will contract personnel with a higher level of education than is in fact required. In view of the fact that the match between education and occupational levels which is actually achieved constitutes the basis of the calculation of the required level of education, the level of overeducation is underestimated in case of excess supply and overestimated in case of excess demand. Hartog and Jonker (1997) therefore concluded that the method based on the realized matches is the least adequate one for determining overeducation and undereducation.

\subsection{Findings of Study}

We will now present the results of the Study on Overeducation of graduates in Albania. The analysis targets workers who are graduated and employed. The unemployed and the self employed workers are not part of this study. Over a dataset of 576 graduated and employed individuals all over Albania, the first two available techniques were applied to assess the

\footnotetext{
1 Halaby, C. N. (1994). "Overeducation and Skill Mismatch." Sociology of Education 67:47

2 Duncan, G. and Hoffman, S. (1981). The incidence and wage effects of overeducation. Economics of Education Review No.1

3 Cohn, E. and Khan, S.P. (1995) The wage effects of over schooling revisited, Labour Economics, No 2.

4 Hartog, J.\&Jonker, N. , A Job to Match your Education: Does it Matter? Paper presented at the ROA 10th Anniversary Conference, Maastricht. (1998), Towards a transparent labour market for educational decisions, Avebury

5 Verdugo, R. R. and N. T. Verdugo (1989). "The impact of schooling surplus on earnings: Some additional findings." Journal of Human Resources

6 Kiker, B., Santos, M., and de Oliveira, M. (1997). Overeducation and under education: evidence for Portugal. Economics of Educational Review, Vol 16, Issue no.2
} 
incidence of over education attainment. We focus on the below outcomes: the incidenceofcurrentovereducation, its characteristic as gender, age-group, geographical distribution, field of study accomplished, etc.

\section{a. Self Report Method}

The elaboration of collected data from the study' target group and their analysis by the Direct Self-Evaluation Method reveal that overeducation phenomenon is present in $65.9 \%$ of the respondents.

Table 1: Overeducation by Gender

\begin{tabular}{|c|c|c|c|c|}
\hline & & \multicolumn{2}{|c|}{ Overeducation Definition } & \multirow[t]{2}{*}{ Tota } \\
\hline & & Normal & Overeducated & \\
\hline \multirow[t]{2}{*}{ Gender: } & 1. Female & 122 & 257 & 379 \\
\hline & 2. Male & 74 & 123 & 197 \\
\hline Total & & 196 & 380 & 576 \\
\hline
\end{tabular}

\section{Graphic 3}

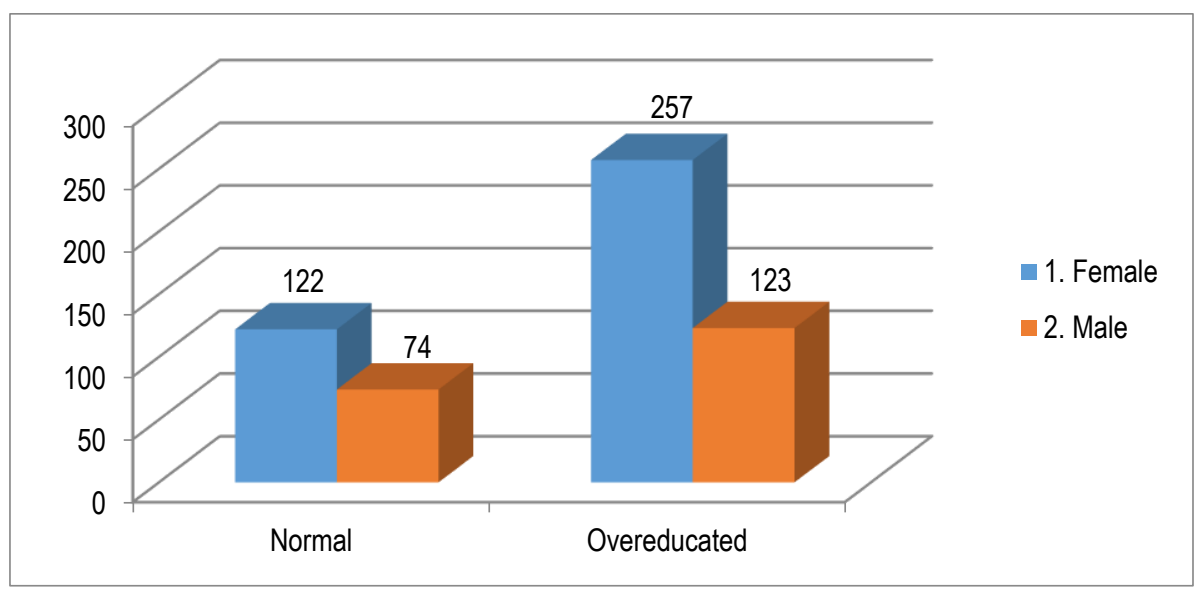

As seen from the chart, overeducated women constitute $67.8 \%$ of the total of those interviewed, while the men $62.4 \%$.In total overeducated persons constitute $65.97 \%$ of the total of those interviewed.

Table 2: Overeducation by age

\begin{tabular}{|c|c|c|c|}
\hline \multicolumn{4}{|c|}{ Overeducation Definition } \\
\hline Age & Normal & Overeducated & Total \\
\hline
\end{tabular}




\begin{tabular}{|l|l|l|l|}
$21-29$ years & 75 & 209 & 284 \\
\hline $30-39$ years & 59 & 87 & 146 \\
\hline $40-49$ years & 39 & 54 & 93 \\
\hline $50-55$ years & 9 & 22 & 31 \\
\hline Over 55 years & 14 & 8 & 22 \\
\hline & 196 & 380 & 576 \\
\hline
\end{tabular}

\section{Graphic 4: Overeducation by age}

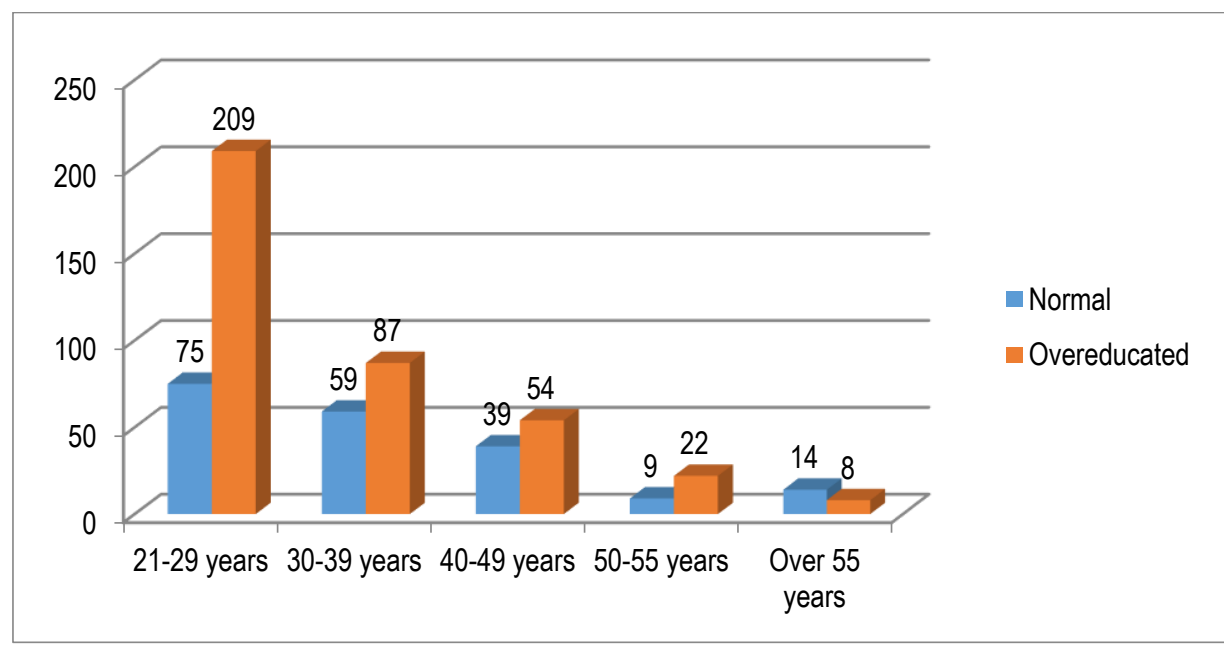

From the datas in table we can see that, the overeducation is present more in young ages, more specifically on the 21-29 years old group, which constitutes $55 \%$ of the total number of overeducated individuals.

Table 3: Overeducation by prefecture

\begin{tabular}{|l|l|l|l|}
\hline & \multicolumn{2}{|l|}{ Overeducation Definition } & Total \\
\hline District & Normal & Overeducated & \\
\hline Tirana & 78 & 167 & 245 \\
\hline Durrës & 11 & 31 & 42 \\
\hline Elbasan & 17 & 43 & 60 \\
\hline Shkodër & 20 & 12 & 32 \\
\hline Diber & 3 & 6 & 9 \\
\hline Fier & 8 & 26 & 34 \\
\hline Vlorë & 13 & 26 & 39 \\
\hline Korcë & 22 & 20 & 42 \\
\hline
\end{tabular}




\begin{tabular}{|l|l|l|l|} 
Gjirokastër & 10 & 16 & 26 \\
\hline Kukës & 6 & 4 & 10 \\
\hline Lezhë & 6 & 11 & 17 \\
\hline Berat & 2 & 18 & 20 \\
\hline Total & 196 & $\mathbf{3 8 0}$ & $\mathbf{5 7 6}$ \\
\hline
\end{tabular}

Analyse from the perspective of district shows that the biggest number of overeducated graduates is in Tirana, the capital of Albania and constitutes $44 \%$ of the total number of overeducated individuals. This is expected as Tirana host many public institutions and public and private universities, and is the centre of the political, economic, and cultural life of the country. It is followed by Elbasani and Durresi, both city hosting public and private universities as well.

Graphic 5: Overeducation by prefecture

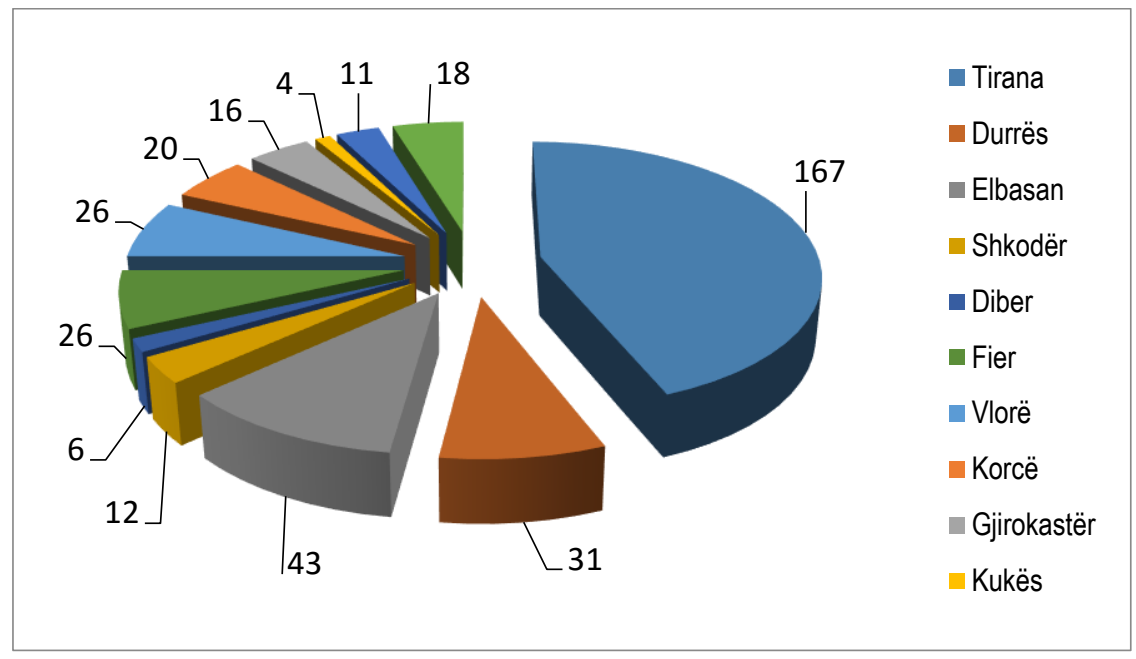

Table 4: Overeducation by field of study

\begin{tabular}{|l|l|l|l|}
\hline & \multicolumn{2}{|l|}{ Overeducation Definition } & Total \\
\hline Field of Study Accomplished & Normal & Overeducated & \\
\hline Education Sciences & 24 & 28 & 52 \\
\hline Humanitarian \& Art Sciences & 18 & 54 & 72 \\
\hline $\begin{array}{l}\text { Social, Economical Sciences and } \\
\text { Law }\end{array}$ & 107 & 187 & 294 \\
\hline Natural Sciences & 17 & 24 & 41 \\
\hline Enginiering Sciences & 16 & 44 & 60 \\
\hline Agriculture \& Veterinary & 3 & 11 & 14 \\
\hline Health \& Wellbeing & 11 & 31 & 42 \\
\hline
\end{tabular}




\begin{tabular}{|l|l|l|l|} 
Services & 0 & 1 & 1 \\
\hline & $\mathbf{1 9 6}$ & $\mathbf{3 8 0}$ & $\mathbf{5 7 6}$ \\
\hline
\end{tabular}

Graphic 6: Overeducation by field of study

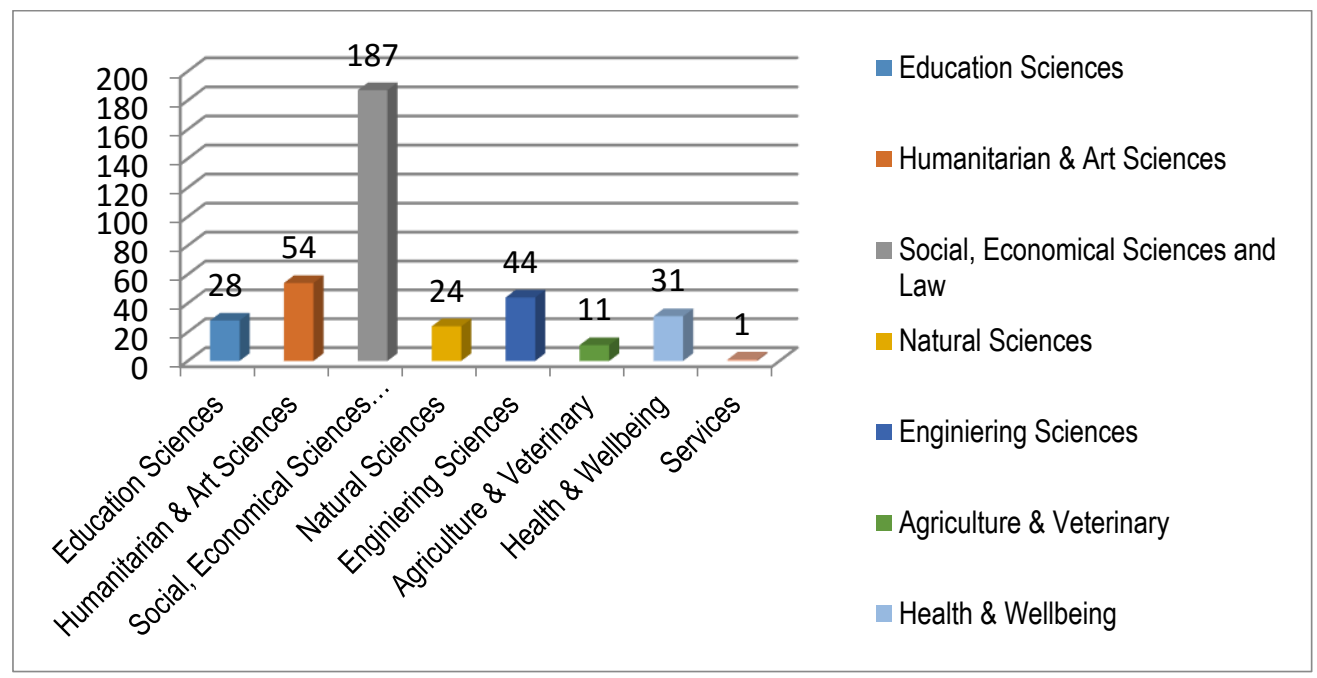

Over-education rates vary considerably across fields of study, with lower rates for "professional" fields of natural sciences, educational sciences and medicine. Conversely higher rates of over-education affect graduates of Social, Economical, and Law sciences as well Humanitarian \& Art Sciences.

The study provised evidence that graduates from Social, Economic and Law field of studies have an increased risk of being overeducated as it constitutes $49.2 \%$ of all target group of this study. However, some degrees offer greaterprotection against the likelihood of genuine overeducation.

Table 5: Overeducation by type of working Institution

\begin{tabular}{|l|l|l|l|}
\hline & \multicolumn{2}{|l|}{ Overeducation Definition } & Total \\
\hline $\begin{array}{l}\text { Where are you } \\
\text { actually employed }\end{array}$ & Normal & Overeducated & \\
\hline Public Institutions & 102 & 172 & 274 \\
\hline Privat Institutions & 82 & 181 & 263 \\
\hline $\begin{array}{l}\text { Foreign } \\
\text { Organisations }\end{array}$ & 8 & 17 & 25 \\
\hline Albanian NGO & 4 & 10 & 14 \\
\hline Total & 196 & 380 & 576 \\
\hline
\end{tabular}

Graphic 7: Overeducation by type of working Institution 


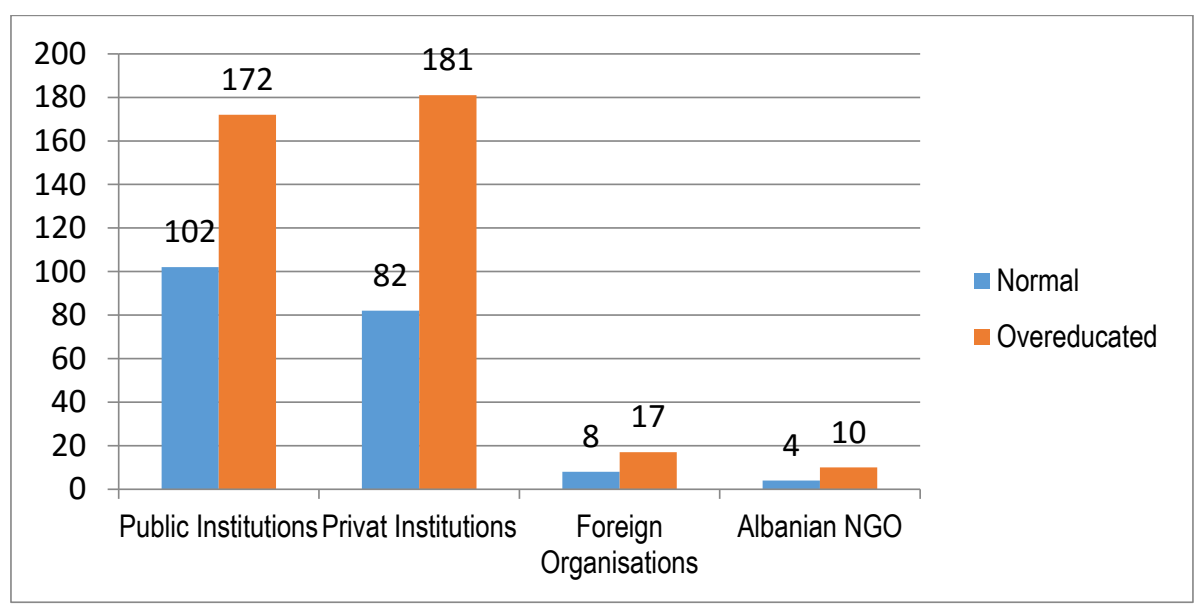

From the datas of this study can be argued that the overeducation rate is not influenced by the type of institution, the respondents are working in. Both public and private sector have a large number of overeducated employees.

\section{b. Job Analyst Method}

In this part of analysis we define overeducation according to a job analysis approach. Each position in this survey data has been coded following the National List of Occupations in Albania. This classification groups jobs according to a set of tasks to be executed and assigns to each occupation an educational level that is the most appropriate. The following functional levels are considered: General Middle School, Vocational Middle School, Bachelor, Master and PhD.

ccording to the job analysis method within the retained sample $57.11 \%$ of the jobs were filled by overeducated workers, whereas only $65.9 \%$ according to the direct self-assessment method.

Table 6: Overeducation by List of Occupations

\begin{tabular}{|l|l|l|l|}
\hline & \multicolumn{2}{|l|}{ Overeducation Definition } & Total \\
\hline $\begin{array}{l}\text { In which group of professions are you } \\
\text { actually employed }\end{array}$ & Normal & Overeducated & \\
\hline Armed Forces and Military & 0 & 1 & 1 \\
\hline $\begin{array}{l}\text { Legislators and senior official of the state } \\
\text { administration and executives }\end{array}$ & 11 & 17 & 28 \\
\hline High Education Specialists & 79 & 139 & 218 \\
\hline Technicians and specialist & 59 & 109 & 168 \\
\hline Administrative clerks & 17 & 29 & 46 \\
\hline Sales and Services Employees & 30 & 84 & 114 \\
\hline Elementary occupations & 0 & 1 & 1 \\
\hline & $\mathbf{1 9 6}$ & $\mathbf{3 8 0}$ & $\mathbf{5 7 6}$ \\
\hline
\end{tabular}


Graphic 8: Overeducation by List of Occupations

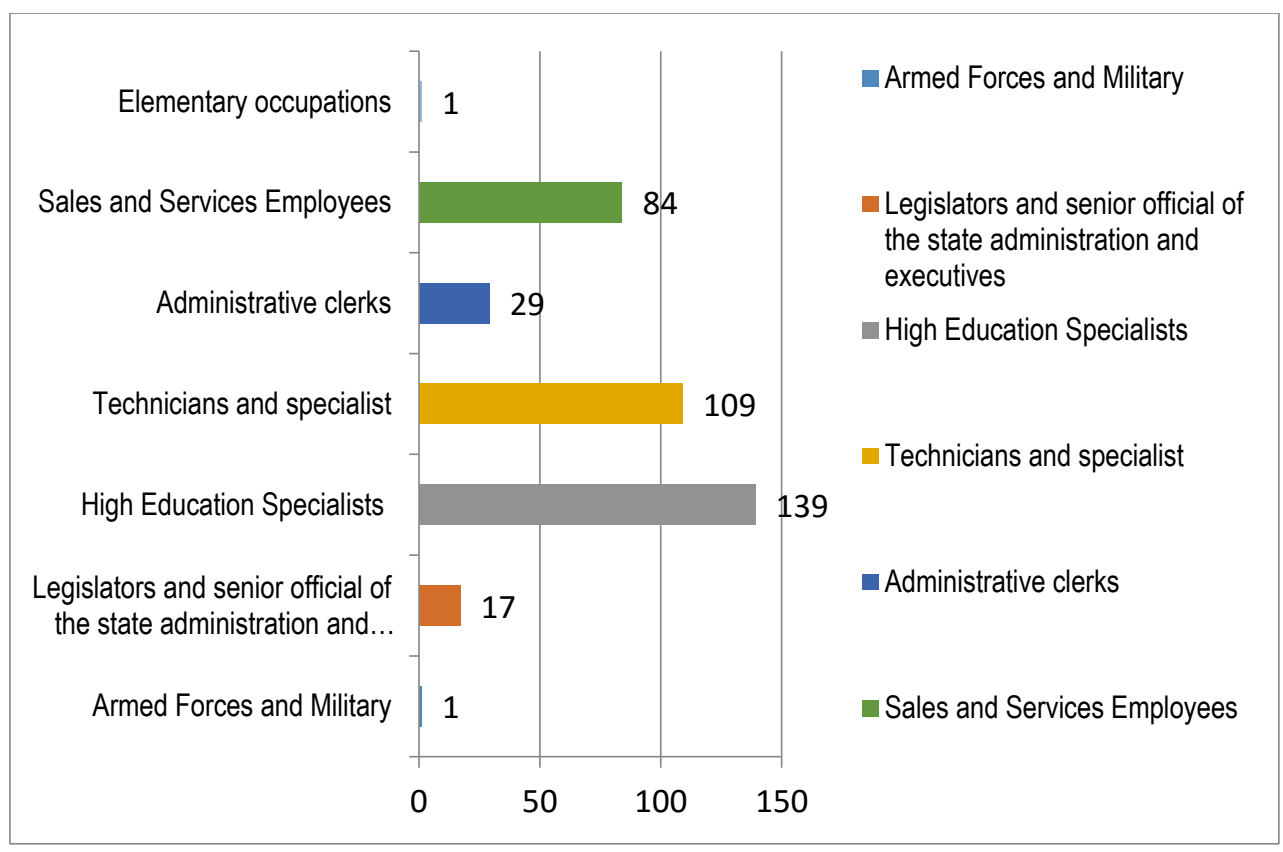

Groups in this List of Occupations were based on the National List of Occupations approved by Decision of Council of Ministers No.627, dated 11.6.2009, which provides a standardized language for describing the work carried out in the labour market. There are 10 main groups. The relationship between these groups and four levels of competence are given in the following table

Table 7: List of Occupations and the respective education level 


\begin{tabular}{|r|l|r|r|}
\hline No & Main Groups of Occupation List & $\begin{array}{c}\text { Competency } \\
\text { Level }\end{array}$ & Education Level Categories \\
\hline & $\begin{array}{l}\text { Legislators and senior official of the state administration and } \\
\text { executives }\end{array}$ & $3+4$ & Tertiary Education \&Post Tertiary Education \\
\hline 2 & High Education Specialists & 4 & Tertiary Education \&Post Tertiary Education \\
\hline 3 & Technicians and specialist & 3 & Post-secondary non-tertiary level of education \\
\hline 4 & Administrative clerks & 2 & General \& Vocational Middle School Education \\
\hline 5 & Sales and Services Employees & 2 & General \& Vocational Middle School Education \\
\hline 6 & Employees of agriculture, forestry and fishing & 2 & General \& Vocational Middle School Education \\
\hline 7 & Craft trades and related occupations & 2 & General \& Vocational Middle School Education \\
\hline 8 & Employees of assembly and use of machines and equipments & 2 & General \& Vocational Middle School Education \\
\hline 9 & Elementary occupations & 1 & Elementary Education \\
\hline 10 & Armed Forces and Military & $1+4$ & Elementary Education \& Tertiary Education \\
\hline
\end{tabular}

According to the self declaration made by persons in connection with the group they belong and classification in the above table shows that we have overeducated employees as follows:

Table 8: Employment as per group of professions

\begin{tabular}{|l|l|l|l|l|}
\hline No & $\begin{array}{l}\text { In which group of professions are you actually } \\
\text { employed according to the National List of } \\
\text { Occupations }\end{array}$ & $\begin{array}{l}\text { No. of } \\
\text { persons } \\
\text { interviewed }\end{array}$ & Overeducated & Normal \\
\hline 1 & $\begin{array}{l}\text { Legislators and senior official of the state } \\
\text { administration and executives }\end{array}$ & 28 & & 28 \\
\hline 2 & High Education Specialists & 218 & & 218 \\
\hline 3 & Technicians and specialist & 168 & 168 & \\
\hline 4 & Administrative clerks & 46 & 46 & \\
\hline 5 & Sales and Services Employees & 114 & 114 & \\
\hline 9 & Elementary occupations & 1 & 1 & 1 \\
\hline 10 & Armed Forces and Military & 1 & & 247 \\
\hline & Total & 576 & 329 & \\
\hline
\end{tabular}

\subsection{Is overeducation a temporary disequilibrium or a permanent feature of economy?}

The table below presents an overview of all persons interviewed and their educational level.

\section{Table 9:}

\begin{tabular}{|l|l|l|l|l|l|l|}
\hline & \multicolumn{4}{|l|}{ The Highest Level of Education completed } & \\
\hline & & & & & The old system of \\
Education level of the start of the work & Bachelor & Master & PhD & High Education & $\begin{array}{l}\text { Other } \\
\text { Specify }\end{array}$ & Total \\
\hline General middle school & 34 & 15 & 0 & 12 & 0 & 61 \\
\hline Vocational midde school & 8 & 3 & 0 & 8 & 0 & 19 \\
\hline
\end{tabular}




\begin{tabular}{|l|l|l|l|l|l|l|} 
Bachelor & 46 & 61 & 1 & 41 & 2 & 151 \\
\hline Master & 8 & 61 & 2 & 68 & 4 & 143 \\
\hline The old system of High Education & 4 & 13 & 6 & 119 & 2 & 144 \\
\hline I don't know/ I don't remember & 14 & 18 & 0 & 26 & 0 & 58 \\
\hline Total & 114 & 171 & 9 & 274 & 8 & 576 \\
\hline
\end{tabular}

From the calculations made by comparing the Educational level at the start of work and the actual level education it appears as follows:

- 175 Individuals were normal at the start of the work and currently.

- 365 Individuals have been overeducated at the start of the work and currently.

-21 Individuals have been overeducated at the start of work and are currently normal

- 15 Individuals have been normal at the start of the work and are currently overeducated

\section{Table 10}

\begin{tabular}{|l|l|l|l|l|}
\hline & \multicolumn{4}{|l|}{ Overeducation at the start of work } \\
\hline \multirow{5}{*}{ Overeducation Actually } & & Normal & Overeducated & Total \\
\hline & Normal & 175 & 21 & 196 \\
\cline { 2 - 6 } & Overeducated & 15 & 365 & $\mathbf{3 8 0}$ \\
\cline { 2 - 6 } & Total & 190 & $\mathbf{3 8 6}$ & $\mathbf{5 7 6}$ \\
\hline
\end{tabular}

Table 11

\begin{tabular}{|c|c|c|c|c|c|}
\hline $\begin{array}{l}\text { Number of years } \\
\text { working in the actual } \\
\text { job }\end{array}$ & Normal always & $\begin{array}{l}\text { From Normal to } \\
\text { Overeducated }\end{array}$ & \begin{tabular}{|l|} 
From \\
Overeducated \\
to Normal
\end{tabular} & $\begin{array}{l}\text { Overeducated } \\
\text { always }\end{array}$ & Total \\
\hline 0 & 26 & 1 & 11 & 98 & 136 \\
\hline 1 & 17 & 2 & 3 & 64 & 86 \\
\hline 2 & 23 & $\mathrm{O}$ & 1 & 49 & 73 \\
\hline 3 & 10 & 2 & 1 & 23 & 36 \\
\hline 4 & 12 & 1 & 0 & 21 & 34 \\
\hline 5 & 16 & 1 & 1 & 22 & 40 \\
\hline 6 & 10 & 0 & 0 & 11 & 21 \\
\hline 7 & 6 & 3 & 1 & 13 & 23 \\
\hline 8 & 14 & $\mathrm{O}$ & 2 & 9 & 25 \\
\hline 9 & 6 & 2 & 0 & 6 & 14 \\
\hline 10 & 4 & 0 & 0 & 8 & 12 \\
\hline 11 & 2 & 1 & $\mathrm{O}$ & 5 & 8 \\
\hline 12 & 4 & 0 & 0 & 5 & 9 \\
\hline 13 & 4 & $\mathrm{O}$ & 0 & 4 & 8 \\
\hline 14 & 1 & 0 & $\mathrm{O}$ & 4 & 5 \\
\hline 15 & 5 & 0 & $\mathrm{O}$ & 5 & 10 \\
\hline 16 & 1 & 0 & $\mathrm{O}$ & 5 & 6 \\
\hline 17 & 1 & 2 & 0 & 0 & 3 \\
\hline 18 & o & $\mathrm{O}$ & 0 & 2 & 2 \\
\hline 20 & 4 & 0 & 1 & 1 & 6 \\
\hline 22 & 3 & 0 & 0 & 3 & 6 \\
\hline 23 & 1 & 0 & $\mathrm{O}$ & 0 & 1 \\
\hline 24 & 1 & 0 & 0 & 0 & 1 \\
\hline 25 & 1 & 0 & 0 & 0 & 1 \\
\hline 26 & 요 & 0 & 0 & 1 & 1 \\
\hline 28 & 1 & 0 & 0 & 2 & 3 \\
\hline 29 & 0 & 0 & 0 & 1 & 1 \\
\hline 30 & 0 & 0 & 0 & 2 & 2 \\
\hline 34 & 1 & 0 & 0 & 0 & 1 \\
\hline 35 & 0 & 0 & 0 & 1 & 1 \\
\hline 37 & 1 & 0 & 0 & 0 & 1 \\
\hline Total & 175 & 15 & 21 & 365 & 576 \\
\hline
\end{tabular}


From the above table we can see that if we analyse deeper the group of respondants which have results as always overeducated, we see that the biggest number corresponds to those with less years of experience. The person with less than 7 years of experience constitutues $82.46 \%$ of the total number of individuals who have resulted always overeducated.

\section{Graphic 9}

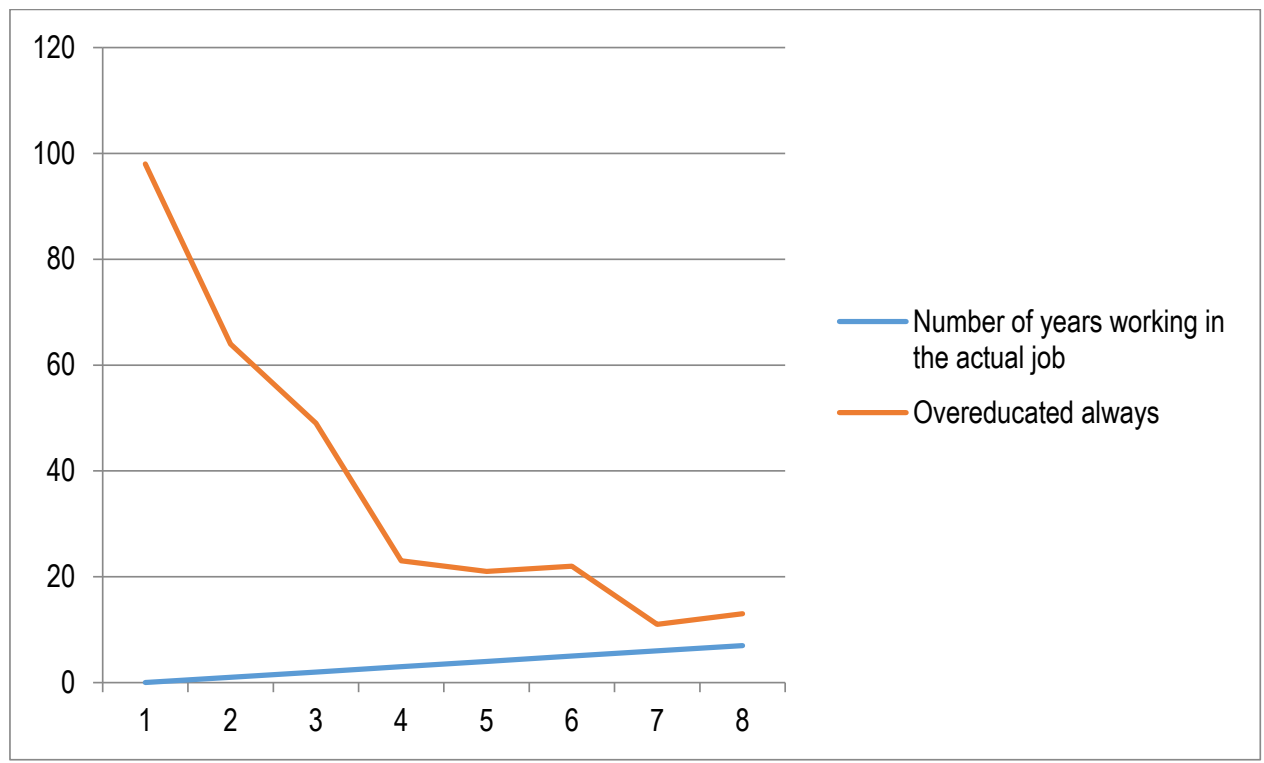

So as per our datas, overeducation seems to be a temporary phenomenon, as it is present more in the first years of works.

\section{Conclusions \& Recommandations}

From the findings of the study, we can interpret that the education system does not provide the type of education that enable people with the right level of required skills, employment opportunities, given their formal education. Despite the different reasons that justify the discrepancy between the education level and employment level, another possible explanation may be the "inappropriate" investment in human capital, since these employees have a much higher educational level than needed by the workplace.

The paper therefore raises a number of important issues for policy. The obvious implication, therefore, is that should higher education participation continue to expand, than rates of overeducation will inevitably rises incurring further costs on individuals, firms and the economy. It is also clear that, particularly at the graduate level, the incidence of overeducation is non-random with respect to subject studied, so graduates from backgrounds such as Social Sciences, Economy and Law are much more likely to end up overeducated. This raises the question with respect to the extent to which government should seek to re-orientate the educational system away from the Social Sciences, Economy and Law towards more vocationally orientated subjects with higher levels of job relevant skills. Nevertheless, it is likely that such a strategy, whilst providing some benefits, is unlikely to provide a solution to overeducation, as the evidence suggests that the problem effectively relates to the supply of educated labour exceeding demand coupled with an inflexible labour market, whereby employers are either unable or unwilling to alter their production processes to fully utilize the skills of their overeducated workers.

Any assessment of the Albanian labor market for graduates including the conclusions reached in this study - are open to debate, while is still a lack of information about market demand and employment of graduates. Development of systems for efficient information will help in informing government, policy makers, donors, universities and other stakeholders about the current and future labor market, enabling an effective and accountable higher education.

There is a need for a clear vision of the graduate demand to enable the construction of an effective system of higher education that addresses the needs and expectations of the growing number of youths who enter the labor market. 
The government should consider analyzing as well the postgraduate projection (for the next five years) to ensure its accuracy.

\section{References}

Freeman,Richard B.(1976) The Overeducated American,Public Choice, Vol. 34, No. 2 (1979)

Becker, W. E. (2004) Economics for a higher education, International Review of Economics Education, volume 3, issue 1

Chevalier, A. ( 2003), Measuring Over education, Economica, no.70

Roth, Felix \&Thum, Anna-Elisabeth (2010), The Key role of Education in Europe 2020 Strategy, Center for European Policy Study, Working Document no.338

Sloane, P.J. (2002). Much ado about nothing: What does the over-education literature really tell us? Keynote Address, International Conference on Over-education in Europe: What Do We Know? November 22,23, Berlin, Germany

Trow M. Problems in the Transition from Elite to Mass Higher Education. Carnegie

Commission on Higher Education 1973

Trow, M. (2006). Reflections on the Transition from Elite to Mass to Universal Access: Forms and Phases of Higher Education in Modern Societies since WWII. In: Altbach P., Forest J. (Eds.). International Handbook of Higher Education, vol.1

Rumberger, R.W (1981b), 'The Rising Incidence of Overeducation in the US Labor Market', Economics of Education Review, vol. 1, no. 3 .

Rumberger, R.W (1984), The changing economic benefits of college graduates, Economics of Education Review, vol. 3, issue no.1

Rumberger, R.W (1987), 'The Impact of Surplus Schooling on Productivity and Earnings', The Journal of Human Resource, vol. 22, no. 1.

Duncan, G. and Hoffman, S. (1981). The incidence and wage effects of overeducation. Economics of Education Review No.1

Smith, H.L. (1986), Overeducation and underemployment; An Agnostic Review, Sociology of Education no.59

Burris, V. (1983). The social and political consequences of overeducation. American Sociological Review, no.48

Cohn, E. and Khan, S.P. (1995) The wage effects of over schooling revisited, Labour Economics, No 2.

Hartog, J.\&Jonker, N. , A Job to Match your Education: Does it Matter? Paper presented at the ROA 10th Anniversary

Conference, Maastricht. (1998), Towards a transparent labour market for educational decisions, Avebury

Sheppard H.L \& Herrick N.(1972), Where have all the robots gone, worker dissatisfaction in 70s, New York, Free Press

Croce, G., (2011), Overeducation in Europe and Italy, Meridiana No.71/72, Societa Disuguale, 2011.

Gottschalk P. and Hansen M., 2003. Is the Proportion of College Workers in Non-College Jobs Increasing? Journal of Labor Economics, no.21

Bergin, A., McGuinness, S., Whelan, A., (2015), Over education in Europe. Is there scope for common policy approach, The Economic and Social Research Institute, Irish Economy Conference

Verdugo, R. R. and N. T. Verdugo (1989). "The impact of schooling surplus on earnings: Some additional findings." Journal of Human Resources 24: 629.

Halaby, C. N. (1994). "Overeducation and Skill Mismatch." Sociology of Education 67:47

Hartog, J. (2000). "Over-education and earnings: where are we and where should we go?" Economics of Education Review 19: 131

Sicherman, N. (1991). "Overeducation" in the labor market. Journal of Labor Economics, Vol. 9, Issue no.2

Kiker, B., Santos, M., and de Oliveira, M. (1997). Overeducation and under education: evidence for Portugal. Economics of Educational Review, Vol 16, Issue no.2

Kler, P. 2005,'Graduate overeducation in Australia: a comparison of the mean and objective methods', Education Economics, vol.13 
Boothby, D 2002,Literacy skills, occupational assignment and the returns to over education and under-education, No.9, Statistics Canada, Ottawa

De Weert,Egbert (2011),Perspectives on Higher Education and Labour Market, Center for Higher Education Policy Studies Institute of Statistics- INSTAT www.instat.gov.al

http://ec.europa.eu/europe2020/index_en.htm

Public Accreditation Agency for Higher Education, http://www.aaal.edu.al/ 